\title{
The Relationship between the Saudi Cadets' Learning Motivation and Their Vocabulary Knowledge
}

\author{
Ali Falah Alqahtani ${ }^{1}$ \\ ${ }^{1}$ Department of Languages, King Abdulaziz Military Academy, Saudi Arabia \\ Correspondence: Ali Falah Alqahtani, Department of Languages, King Abdulaziz Military Academy, Riyadh, \\ Saudi Arabia.
}

Received: February 10, 2020

Accepted: March 6, 2020

Online Published: March 11, 2020

doi: 10.5539/elt.v13n4p1

URL: https://doi.org/10.5539/elt.v13n4p1

\begin{abstract}
This paper is a report on the study of the relationship between foreign/second language (L2) motivation and vocabulary knowledge. The population of the study is the cadets of a military academy in Saudi Arabia who study English as a foreign language. The total number of participants is 195 Saudis. The author uses the L2 Motivational Self System to investigate the cadets' L2 motivation and the vocabulary test "X-Lex" (Meara \& Milton, 2003) to measure their vocabulary size (VS). The correlation analysis shows a positive moderate statistical correlation between the students' L2 motivation and their VS because the Ideal L2 Self, the Language Learning Attitudes, and the Intended Learning Effort had a linear relationship with the VS. Nevertheless, the regression analysis reveals that none of these motivational scales is a predictor of the students' VS. Finally, the correlation analysis and the regression analysis disclose a statistically significant correlation between the Saudi cadets' self-perception as competent English users and their L2 motivation as well as their VS.
\end{abstract}

Keywords: ideal L2 self, language learning attitudes, motivational self system, ought-to L2 self, vocabulary size, X-Lex

\section{Introduction}

Vocabulary is essential for communication because, without a sufficiently large vocabulary, any successful communication is difficult to accomplish. Wilkins (1972) thought that "without grammar very little can be conveyed, without vocabulary nothing can be conveyed" (p. 111). Therefore, vocabulary acquisition is significant in foreign/second language (L2) use because it plays a pivotal role in the formation of successfully completed written and spoken texts. In other word, a lack of sufficient vocabulary knowledge (VK) makes understanding a text an impossible task (Nation, 2011). According to Cortazzi and Jin (1996), L2 learners mainly focus on acquiring vocabulary over other aspects of language learning. Because L2 learners believe that vocabulary is an important component of their language learning, most of their struggles in this area arise from their lack of VK (Nation, 1990).

Scholars such as Laufer and Nation (1999), Gu (2003), and Read (2011) assert the close relationship between foreign language learning and vocabulary size (VS). Vocabulary learning enables L2 learners to be successful in their L2 learning process (Nation, 2011). In many English as a foreign language (EFL) classrooms, teachers focus mainly on grammar and pay little attention to vocabulary building despite its importance in acquiring the target language and helping the L2 learners to communicate with others (Albodakh \& Cinkara, 2017).

Williams and Burden (1997) defined motivation as "a state of cognitive and emotional arousal, which leads to a conscious decision to act ... in order to attain a previously set goal (or goals)" (p. 120). Learning an L2, which is a sustained long-term activity that may last for years, can be regarded as a conscious decision that the learner undertakes to achieve previously set goals such as conversing with people who cannot speak his or her language. This makes learning an L2 unique and different from other school subjects because a foreign language "is not a socioculturally neutral field but is affected by a range of sociocultural factors such as language attitudes, cultural stereotypes, and even geopolitical considerations" (Dörnyei, 2005, p. 67).

Numerous researchers have examined the relationship between VK (usually using measures of VS) and a variety of language proficiency measures, such as reading e.g. (Albrechtsen, Haastrup, \& Henriksen, 2008), speaking e.g. (Daller, Van Hout, \& Treffers-Daller, 2003), grammatical accuracy e.g. (Alderson, 2005), writing e.g. (Yu, 
2010), listening e.g. (Stæhr, 2008), and academic achievement e.g. (Masrai \& Milton, 2017). Only a few authors have examined the relationship between vocabulary knowledge and language learning motivation (L2 motivation) e.g. Gardner and MacIntyre. (1991). This study will constitute an attempt to fill this gap by addressing the relationship between the L2 motivation and VK of Saudi military cadets. The author will examine the relationship in this underresearched context through the lens of one of the contemporary models in L2 motivation, the L2 Motivational Self System (L2MSS) (see the literature review section for details).

\section{Literature Review}

\subsection{The L2MSS}

Gardner and Lambert (1959) were the pioneers who investigated the relationship between learning an L2 and motivation. They developed a sociopsychological model with integrativeness as its core construct, which was used for decades to investigate L2 motivation. Integrativeness refers to "a sincere and personal interest in the people and culture represented by the other group"; in other words, language learners "must be willing to identify with members of another ethnolinguistic group and take on very subtle aspects of their behaviour" (Gardner \& Lambert, 1972, p. 135).

Nowadays English, as a Lingua Franca, is widely accepted, and the ownership of English is not associated with specific Anglophone cultures and their peoples; scholars such as Yashima (2002), Dörnyei and Csizér (2002), and Dörnyei (2005) doubt the validity of the application of "integrativeness" in such a globalized contemporary world. Thus L2 learners do not necessarily learn English to integrate with the peoples of these Anglophone countries or their cultures. These scholars believe that L2 learners' motivation "might be better explained as an internal process of identification within the person's self-concept, rather than identification with an external reference group" (Dörnyei \& Csizér, 2002, p. 453). Consequently, Dörnyei (2005) proposed a new model: the L2MSS.

Dörnyei (2005) proposed his model, the L2MSS, by drawing on the "possible selves" (Markus \& Nurius, 1986) and "self-discrepancy" (Higgins, 1987). His model is made up of three constructs: Ideal L2 Self (IL2S), Ought-to L2 Self (OL2S), and L2 Learning Experience (L2LE). The IL2S is the L2 learners' vision of themselves as a successful and/or competent L2 user, which they would like to become. Therefore, the IL2S represents the hopes and aspirations that drive the L2 learners to put in more effort in hopes of reducing the discrepancy between their current selves and their ideal future selves. This makes the IL2S more internalized by nature. On the other hand, the OL2S is more extrinsic because it represents the attributes that L2 learners believe they should possess to be able to avoid unpleasant outcomes (e.g., failing an exam) and/or meet the wishes and expectations of significant others (e.g., parents). The third construct, the L2LE, refers to "situation-specific motives related to the immediate learning environment and experience" (Dörnyei, 2005, p. 106). Consequently, issues relevant to the immediate learning environment, such as the impact of the L2 teacher, the peer group, the experience of success, and the curriculum, belong to the L2LE.

Of the three constructs of the L2MSS, the IL2S is the most salient because it has been found in almost all the previous studies that it is the most significant variable in predicting the learning effort of L2 students (Alqahtani, 2018b; Csizér \& Kormos, 2009; Kormos, Kiddle, \& Csizér, 2011; Taguchi, Magid, \& Papi, 2009). In some studies, the IL2S accounted for more than $40 \%$ of the variance in the learning effort of L2 students, such as $45 \%$ in Alqahtani's (2018a) study. In the field of L2 motivation studies, these figures can be regarded as exceptionally high (Dörnyei \& Ushioda, 2011). Furthermore, the results of some studies, such as Csizér and Kormos (2009) and Kormos et al. (2011), reveal the other two constructs of the L2MSS (the OL2S and the L2LE) to have a direct impact on the IL2S.

Some scholars have found the influence of the OL2S on the learning effort of L2 students to be minimal (Kormos et al. (2011) Lamb (2012)). Therefore, scholars such as Kormos et al. (2011) and Taguchi et al. (2009) suggest that the OL2S is likely to have a more salient role in Arab and Asian contexts, where the expectations of students' parents can be powerful motivators. The impact of the OL2S on the learning effort of L2 Saudi students was salient in Alqahtani's (2017a) study. In addition, it has been found in a number of studies, such as Csizér and Kormos (2009), Kormos et al. (2011), and Taguchi et al. (2009), that the OL2S was directly influenced by parental encouragement, which led Csizér and Kormos (2008a) to conclude that "the OL2S is entirely socially constructed" (p. 177).

Similar to the IL2S, the third construct of the L2MSS (the L2LE) has a significant impact on the learning effort of L2 students. The results of a number of studies reveal an even stronger impact (Alqahtani, 2017b; Csizér \& Kormos, 2009; Islam, Lamb, \& Chambers, 2013). The L2LE has been referred to using a number of terms interchangeably; for example, "Language Learning Attitudes" (LLA) (Alqahtani, 2018a; 2018b), "Attitudes to 
L2 Learning" (You, Dörnyei, \& Csizér, 2016), "Attitudes to Learning English" (Islam et al., 2013), and "L2 Learning Attitude" (Csizér \& Kormos, 2008b). In this study, the third construct of the L2MSS is referred to as LLA.

\subsection{Vocabulary Knowledge}

VK can be divided into two main dimensions; the breadth of the knowledge refers to "the number of the words for which the person knows at least some of the significant aspects of meaning" (Anderson \& Freebody, 1981, p. 92). The second dimension is called the depth or quality of the VK; here the learner needs to "know a great deal about each individual lexical item in order to use it well" (Schmitt, 2010, p. 15).

The breadth of the VK is fundamental to the lexical capability of L2 learners. It has been found that learners with a high amount of VS are more flexible in comprehension and language use in comparison to learners with limited VS (Meara, 1996). Alderson (2005) asserted that "the size of one's vocabulary is relevant to one's performance on any language test, in other words, that language ability is to quite a large extent a function of VS" (p. 88).

Learners need a good VS (i.e., breadth of VK) to function in a language. They also need to know a great deal about these individual lexical items to be able to use them efficiently (i.e., depth of VK). Therefore, the learners need to possess more than just a superficial understanding of a word's meaning. Read (2004) averred that learners should "develop a rich and specific meaning representation as well as knowledge of the word's formal features, syntactic functioning, collocational possibilities, register characteristics, and so on" (p. 155). Therefore, in comparison to learners with lower vocabulary proficiency, learners with higher proficiency are more efficient language users and are well organized.

The VK concept used in this study refers to the recognition of word form. The VS is a measure used to describe the number of words known by the language learner (Masrai \& Milton, 2017). A number of researchers have found a close link between VK and English language learners' ability and academic achievement, which influences the students' success in English (Daller \& Phelan, 2013; Roche \& Harrington, 2013). In her study of schoolchildren to whom English was taught as an L2, Saville-Troike (1984) concluded that "vocabulary knowledge is the single most important area of L2 competence" (p. 199). A great deal of VK research has shown moderate to high correlations between general VS and the four language skills: for example, writing ability e.g. Stæhr (2008), reading comprehension e.g. Qian (1999), and oral fluency e.g. Milton, Wade, andHopkins (2010). In these studies, VS accounts for "over $50 \%$ of variance in scores in foreign language performance" (Masrai \& Milton, 2017, p. 129).

\subsection{Research Questions}

1. What is the relationship between the Saudi cadets' L2 motivation and their VK?

a) Is there a statistically significant correlation between the three components of the L2MSS and the reported intended learning effort (ILE) among the Saudi cadets?

b) Is there a statistically significant correlation between the three components of the L2MSS and the VS among the Saudi cadets?

c) Is there a statistically significant correlation between the Perceived Self Competence (PSC) and the three components of the L2MSS among the Saudi cadets?

d) Is there a statistically significant correlation between PSC and VS among the Saudi cadets?

\section{Method}

\subsection{Participants}

The population of the study was the cadets from a military academy in Saudi Arabia. Only Saudi male students with a high school certificate are able to join the academy. Female students are not allowed to join. The cadets spend 3 years, two terms each year (i.e., a total of six terms), studying a wide range of civilian as well as military subjects. English is one of the subjects that the cadets study throughout their 3 years in the academy. English has the most credit among the civilian as well as the military subjects because students study English for an average of 8 hours a week. The cadets need to pass all the exams to graduate from the academy. Based on the students' performance in their English tests, they can be nominated for a scholarship to study abroad. This makes English one of the most important subjects that the cadets study at the academy. The sample of this study, which was randomly selected, was the cadets in their first year in the academy (i.e., the elementary level), so the average age of the participants was 19 . The questionnaires used in the study were administered by the author as well as a 
number of his colleagues. Some 195 (23.8\%) of the 819 elementary-level cadets volunteered to participate in the study.

\subsection{Instruments}

\subsubsection{L2 Motivation Questionnaire}

The author used a 5-point Likert-scale questionnaire that he had administered in a previous study to measure the students' L2 motivation and their PSC (Alqahtani, 2018b). The participation of the students in this study was on a voluntary basis. The anonymity of the respondents was assured before the distribution of the questionnaires. The scales of the study are defined, and an example for each scale given, below:

IL2S: to investigate the imagined desired future L2 self that the respondents would like to be. Example: I often imagine myself as someone who is able to speak English.

OL2S: refers to the participants' imagined future L2 self as expected by people they respect, like their parents. Example: If I fail to learn English, I'll be letting other people down.

$\underline{L L A}$ : to investigate the attitudes of the respondents toward their immediate learning environment. Example: I always look forward to my English classes.

ILE: this is the criterion measure, which is used to determine the participants' perception of the effort they devote to the English learning process. Example: I am prepared to expend a lot of effort in learning English.

PSC: a self-rating scale that the respondents used to assess their English competence in the four skills (speaking, listening, writing, and reading). The participants were asked to rate themselves in each skill from $1-5$, with 1 as the lowest value and 5 as the highest. Such an assessment scale is widely used in many SLA studies, for example Alqahtani (2018b), Dewaele (2005), Duan and Barry (2006), and Zhou (2016).

\subsubsection{Testing VS}

In this study, the author used the X-Lex (Meara \& Milton, 2003) to measure the VS for this sample of Saudi cadets. The X-Lex measures the most frequent 5000 receptive words in English in written modality. The test has 120 items: 20 pseudowords (non-words) and 100 real English words. The pseudowords were used to control guesswork. The author and his colleagues asked the cadets to tick the words they knew and leave the words they did not know unticked. The students could obtain the maximum possible score of 5000 when they ticked all the real words and rejected all the pseudowords.

\subsubsection{Data Analysis Procedure}

The software used to analyze the obtained data was IBM SPSS 20. The analysis of the data started with measuring the coefficient of internal consistency for the scales used in the study. This procedure was used to examine the reliability of the used scales. Then the descriptive statistics were obtained (including median, mean, skewness, standard deviation, and kurtosis). Such a procedure was used to help the author describe the characteristics of the sample and check any violation of the variables (Pallant, 2010; Tabachnick \& Fidell, 2007). Finally, in an attempt to investigate the relationships between the scales of the study, correlation and regression analyses were administered.

Regarding the VS of the participants and to proceed further with statistical tests, such as correlation and regression, the participants were divided into five groups (i.e., levels) based on their score in the VS test, with 1 being the lowest value and 5 the highest. The length of the category was calculated by dividing the highest score (4300) by the levels of the score (5): 4300/5 $=860$. See Tables 1 and 2 below for details.

Table 1. Levels of Participants Based on Their VS Test

\begin{tabular}{ccccc}
\hline Degree & Level & VS Test Score & Frequency & Percentage \\
\hline 1 & Very poor & $0-860$ & 74 & 37.9 \\
2 & Poor & $861-1720$ & 63 & 32.3 \\
3 & Good & $1721-2580$ & 42 & 21.5 \\
4 & Very good & $2581-3440$ & 13 & 6.7 \\
5 & Excellent & $3441-4300$ & 3 & 1.5 \\
\hline Total & & & 195 & 100 \\
\hline
\end{tabular}


Table 2. Descriptive Statistics of the Participants' VS Score

\begin{tabular}{cc}
\cline { 2 - 2 } Descriptive statistics & Value \\
\cline { 2 - 3 } Mean & 2.02 \\
Median & 2.00 \\
Standard deviation & 1.002 \\
Skewness & .744 \\
Kurtosis & -.110 \\
\hline
\end{tabular}

\section{Results}

\subsection{Reliability and Descriptive Statistics}

To verify the reliability of the items used in the study, the Cronbach's alpha was calculated. From the Cronbach's alpha values, it can be claimed that the scales of the used questionnaire had attained internal consistency. The Cronbach's alpha values for all the scales were above the minimum acceptable value in social sciences studies, which is .60 (Pallant, 2010). Table 3 shows the Cronbach's alpha coefficient of the scales. Then the skewness and kurtosis values were calculated to assess the normality of the data. When the values of kurtosis and skewness are "0," only then can perfect normal distribution be obtained. Pallant (2010) asserted that obtaining the " 0 " value rarely occurs in social sciences studies. Nevertheless, Tabachnick and Fidell (2007) vouchsafed that data can be regarded as normal when the kurtosis values do not exceed 7.0 and the skewness values do not exceed 2.0, which was attained in this study. See Table 3 for more details.

Next, descriptive statistics (median, standard deviation, and mean) were obtained. These values were used to gain a comprehensive impression of the results and compare the values of the scales. This may have helped to identify which scales scored low/high and to examine variations within the values. For example, Tables 2 and 3 show that the mean values for all the scales with the exception of VS exceeded 3.0 out of 5 . This might be an indication that the participants in this study were highly motivated to learn English and perceived themselves as competent in the language. Nevertheless, the mean score of their VS test showed otherwise, with the mean value below the average at 2.02 .

Table 3. Reliability and Descriptive Statistics of the Scales

\begin{tabular}{cccccccc}
\hline & Variable & $\begin{array}{c}\text { Cronbach' } \\
\text { s Alpha }\end{array}$ & Mean & Median & Std. Dev & Skewness & Kurtosis \\
\hline 1. & IL2S & .818 & 3.88 & 3.88 & .684 & -.781 & .973 \\
2. & OL2S & .700 & 3.33 & 3.33 & .756 & -.465 & .062 \\
3. & LLA & .851 & 3.66 & 3.67 & .822 & -.618 & .523 \\
4. & ILE & .656 & 4.15 & 4.20 & .528 & -.423 & -.183 \\
5. & PSC & .729 & 3.09 & 3.00 & .833 & -.148 & -.477 \\
\hline
\end{tabular}

4.2 Correlation

The correlation analysis was administered to help the author explore the linear relationship that might exist between the scales used in the study. The author followed the instructions of Cohen (1988) regarding the strength of the correlations. When the values of the correlation coefficient between the scales exceeded .50 , only then would the correlation be regarded as strong. A number of correlation coefficient values were strong, and some were moderate. See Table 4 for more details.

The VS scale had a strong linear correlation with the students' perceived competence (.509) and above-moderate linear correlation with their IL2S (.305). This might suggest that when the students' VS increases, it could improve their perception of their competence in L2, which in turn might help them see themselves as competent L2 users in the future. The scale of the students' perception of their competence in L2 also had above-moderate linear correlation with their IL2S (.410), their LLA (.392), and their ILE (.315). This may indicate that when the students perceive themselves as competent future L2 users, they are likely to have positive attitudes toward their L2 learning environment and would be ready to put more effort into their L2 learning process. See Table 4 for more details. 
Table 4. Correlation Coefficient Values for the Scales

\begin{tabular}{lccccccc}
\hline & Scales & 1 & 2 & 3 & 4 & 5 & 6 \\
\hline 1. & VS & - & & & & & \\
2. & IL2S & $.305^{* *}$ & - & & & & \\
3. & OL2S & & $.224^{* *}$ & - & & & \\
4. & LLA & $.231^{* *}$ & $.675^{* *}$ & $.287^{* *}$ & - & & \\
5. & ILE & $.190^{* *}$ & $.584^{* *}$ & $.339^{* *}$ & $.652^{* *}$ & - & \\
6. & PSC & $.509^{* *}$ & $.410^{* *}$ & & $.392^{* *}$ & $.315^{* *}$ & - \\
\hline
\end{tabular}

\subsection{Regression}

The author administered a stepwise multiple regression to ascertain the scales contributing to the learning motivation of the Saudi cadets by predicting the cadets' ILE. Then, the normality and multicollinearity assumptions were tested for violation. Most of the statistical references, such as Pallant (2010) and Tabachnick and Fidell (2007), agree that multicollinearity exists when the value of the bivariate between the scales is 0.7 or above, which the values did not show.

The model of the best predictors for the Saudi cadets' ILE explains $48 \%$ of the variance in their intended effort. In the field of L2 motivation research, such a value is exceptionally high (see the literature review). The model revealed that the three constructs of the Motivational Self System made a significant contribution to predicting the students' ILE. The strongest predictor was the LLA, followed by the IL2S and the OL2S. The model revealed that neither the VS nor the PSC made a significant contribution to the students' L2 motivation. See Table 5 for details.

To determine the scales that contributed to the students' VK, stepwise multiple regression analysis was conducted based on the participants' VS. The regression model explained $26 \%$ of the variance in the latter. The model showed that the PSC alone made a significant contribution to predicting the students' VS. See Table 6 for details.

Finally, a stepwise multiple regression analysis was used with the PSC as the dependent variable to ascertain the scales that contributed to the students' perception of their L2 competence. The regression model explained 34\% of the variance in said perception. The model revealed that the students' VK as well as their positive attitudes toward the L2 learning environment made a significant contribution to predicting this perception. See Table 7 for details.

Table 5. Regression Model Based on ILE as the Dependent Variable

\begin{tabular}{cccc}
\hline \multirow{2}{*}{ Variable } & \multicolumn{3}{c}{ Final Model } \\
\cline { 2 - 4 } & $B$ & SEB & Beta \\
\hline LLA & .28 & .05 & $.44^{*}$ \\
IL2S & .19 & .06 & $.25^{*}$ \\
OL2S & .11 & .04 & .15 \\
& & & \\
$\mathrm{R}^{2}$ & & .48 & \\
F for change in $\mathrm{R}^{2}$ & & $7.75^{*}$ &
\end{tabular}

${ }^{*} \mathrm{p}<.05$

Table 6. Regression Model Based on VS as the Dependent Variable

\begin{tabular}{|c|c|c|c|}
\hline \multirow{2}{*}{ Variable } & \multicolumn{3}{|c|}{ Final Model } \\
\hline & $B$ & $S E B$ & Beta \\
\hline PSC & .61 & .08 & $.51^{*}$ \\
\hline $\mathrm{R}^{2}$ & & .26 & \\
\hline $\mathrm{F}$ for change in $\mathrm{R}^{2}$ & & $67.50^{*}$ & \\
\hline
\end{tabular}

\footnotetext{
$* \mathrm{p}<.05$
} 
Table 7. Regression Model Based on PSC as the Dependent Variable

\begin{tabular}{cccc}
\hline Variable & \multicolumn{3}{c}{ Final Model } \\
\cline { 2 - 4 } & $B$ & SEB & Beta \\
\hline Vocabulary knowledge & .37 & .05 & $.44^{*}$ \\
LLA & .29 & .06 & $.29^{*}$ \\
& & & \\
$\mathrm{R}^{2}$ & & .34 & \\
F for change in $\mathrm{R}^{2}$ & & $23.08^{*}$ & \\
\hline
\end{tabular}

$$
{ }^{*} \mathrm{p}<.05
$$

\section{Discussion}

The correlation analysis showed that the three constructs of the L2MSS (the IL2S, the OL2S, and the LLA) had a strong linear relationship among them as well as with the ILE and the students' perception of their L2 competence. The regression analysis also revealed that the three constructs of the L2MSS contributed to the students' ILE, which is in line with the findings of a number of studies such as Alqahtani (2017b), Alqahtani (2018b), Lamb (2012), and Kormos et al. (2011). The LLA was the best predictor of the participants' ILE, which coincided with the findings of a number of L2 motivation studies such as Kormos et al. (2011), Lamb (2012), and Taguchi et al. (2009). The IL2S was a better predictor of the students' learning effort than the OL2S, which supported the findings of many studies such as Taguchi et al. (2009), Papi (2010), and You and Dörnyei (2016). This may suggest that the Saudi cadets had positive attitudes toward their L2 learning environment based on their realization of the importance of English to their future either at the academy (to pass English exams and graduate) or abroad (for further studies after graduation), which may have helped them create a vision of themselves as future successful English users.

The correlation analysis showed a moderate linear relationship between the Saudi students' VS and aspects of their L2 motivation (the IL2S, the LLA, and the ILE). These results are in line with the findings of Fontecha and Gallego (2012), who found a significant linear correlation between their Spanish EFL learners and their VS. Nevertheless, the regression analysis revealed that none of the motivational scales was a predictor of the students' VS. This coincides with the findings of a number of studies such as Fontecha (2014) in Spain and Albodakh and Cinkara (2017) in Iraq, who found no relationships between the students' L2 motivation and their VS. It is worth mentioning that the regression analysis also revealed that the predictor of the students' VS was their perception of their competence in L2. Therefore, in an attempt to justify the ambivalent findings regarding the relationship between the students' VS and their L2 motivation, the author administered another regression analysis with the students' perception of their L2 competence as the dependent variable. The results showed that besides the VS, the students' positive attitudes toward the learning environment were also a predictor of their perception of their competence in L2. This may suggest that when the students had a good VS, this might have helped them perceive themselves as competent in L2, which in turn helped them have positive attitudes toward their L2 learning environment and invest more effort in their L2 learning process.

Finally, the correlation analysis revealed a linear relationship between the students' perception of being competent in L2 and aspects of their L2 motivation (the IL2S, the LLA, and the ILE). Such findings are in line with a number of L2 motivation studies such as Alqahtani (2018b) and Papi (2010). Furthermore, the regression analysis also showed that the LLA was one of the best predictors of the students' self-perception as competent English users. This supports the findings of a number of studies, such as Taguchi et al. (2009) and Papi (2010). This suggests that when the L2 learners perceived themselves as competent L2 users, this might have helped them develop positive attitudes toward their immediate learning environment as they began to see themselves as future successful L2 users, which in turn spurred them to put more effort into their L2 learning.

\section{Conclusion}

This study addressed the relationship between L2 motivation and the VK of Saudi cadets in a military academy. The author used the L2MSS to investigate the cadets' L2 motivation and the VS test to assess their VK. First, the relationship between the three constructs of the L2MSS and the students' ILE was investigated, and both the correlation analysis and the regression analysis showed a statistically significant correlation among the three components of the L2MSS as well as the ILE. Second, the correlation analysis revealed a moderate statistical correlation between the Saudi students' L2 motivation and their VS in that a number of aspects of their L2 
motivation (the IL2S, the LLA, and the ILE) statistically correlated with their VS. Third, the correlation analysis and the regression analysis showed a statistically significant correlation between the students' perception of themselves as competent L2 users and their L2 motivation. Fourth, the correlation analysis and the regression analysis also revealed a statistically significant correlation between the Saudi cadets' self-perception as competent English users and their VS.

A major limitation of the study was the population because the sample was restricted to male Saudi military cadets given that females are not allowed to join the academy. This means that the generalizability of the findings to the wider Saudi community of L2 learners is limited. Therefore, conducting a similar study in a different learning context with a more balanced mixture of female and male L2 learners is likely to reveal different results.

\section{References}

Albodakh, M., \& Cinkara, E. (2017). The Relationship between Learner Motivation and Vocabulary Size: The Case of Iraqi EFL Classrooms*. Arab World English Journal, 8(2), 279-292. https://doi.org/10.24093/awej/vol8no2.20

Albrechtsen, D., Haastrup, K., \& Henriksen, B. (2008). Vocabulary and Writing in a First and Second Language. London: Palgrave Macmillan UK.

Alderson, J. C. (2005). Diagnosing Foreign Language Proficiency. London: Continuum International Publishing Group.

Alqahtani, A. F. (2017a). The L2 Motivational Self System and Religious Interest among Saudi Military Cadets: A Structural Equation Modelling Approach. International Journal of English Linguistics, 7(5), 84-94. doi: 10.5539/ijel.v7n5p84

Alqahtani, A. F. (2017b). A Study of the Language Learning Motivation of Saudi Military Cadets. International Journal of Applied Linguistics and English Literature, 6(4), 163-172. http://journals.aiac.org.au/index.php/IJALEL/article/view/3186

Alqahtani, A. F. (2018a). English Language Learning Motivation and English Language Learning Anxiety in Saudi Military Cadets: A Structural Equation Modelling Approach. Arab World English Journal, 9(3), 45-60. https://dx.doi.org/10.24093/awej/vol9no3.4

Alqahtani, A. F. (2018b, July 2nd-4th, 2018). A Study of Language Learning Motivation and L2 Anxiety in Saudi Military Cadets. Paper presented at the 10th International Conference on Education and New Learning Technologies Palma, Mallorca, Spain.

Anderson, R. C., \& Freebody, P. (1981). Vocabulary knowledge. In J. T. Guthrie (Ed.), Comprehension and teaching: Research reviews (pp. 77-117). Newark, DE: International Reading Association.

Cohen, J. (1988). Statistical Power Analysis for the Behavioral Sciences (2nd ed.). Hillsdale, NJ: Lawrence Erlbaum Associates.

Csizér, K., \& Kormos, J. (2008a). Modelling the role of inter-cultural contact in the motivation of learning English as a foreign language. Applied Linguistics, 30(2), 166-185. https://doi.org/10.1093/applin/amn025

Csizér, K., \& Kormos, J. (2008b). The Relationship of Intercultural Contact and Language Learning Motivation among Hungarian Students of English and German. Journal of Multilingual and Multicultural Development, 29(1), 30-48. https://doi.org/10.2167/jmmd557.0

Csizér, K., \& Kormos, J. (2009). Learning Experiences, Selves and Motivatied Learning Bhaviour: A Comparative Analysis of Structural Models for Hungarian Secondary and University Learners of English. In Z. Dörnyei \& E. Ushioda (Eds.), Motivation, language identity and the L2 self (pp. 98-119). Bristol: Multilingual Matters.

Daller, H., Van Hout, R., \& Treffers-Daller, J. (2003). Lexical richness in the spontaneous speech of bilinguals. Applied Linguistics, 24(2), 197-222. https://doi.org/10.1093/applin/24.2.197

Daller, M. H., \& Phelan, D. (2013). Predicting international student study success. Applied Linguistics Review, 4(1), 173-193. https://doi.org/10.1515/applirev-2013-0008

Dewaele, J. M. (2005). Sociodemographic, Psychological and Politicocultural Correlates in Flemish Students' Attitudes towards French and English. Journal of Multilingual and Multicultural Development, 26(2), 118-137. https://doi.org/10.1080/01434630508668400 
Dörnyei, Z. (2005). Psychology of the Language Learner: Individual Differences in Second Language Acquisition. Mahwah, N.J.; London Lawrence Erlbaum Associates.

Dörnyei, Z., \& Csizér, K. (2002). Some Dynamics of Language Attitudes and Motivation: Results of a Longitudinal Nationwide Survey. Applied Linguistics, 23(4), 421-462. https://doi.org/10.1093/applin/23.4.421

Dörnyei, Z., \& Ushioda, E. (2011). Teaching and Researching Motivation. Harlow: Longman.

Duan, G., \& Barry, M. S. (2006). Acculturation and achievement in English among Chinese immigrant adolescents : a comparison of two populations which vary in the density of speakers of Chinese. (PhD), Auburn University, Auburn, Ala. Retrieved from http://repo.lib.auburn.edu/2006\%20Spring/doctoral/DUAN_GUIYONG_19.pdf Available from http://worldcat.org /z-wcorg/ database.

Fontecha, A., \& Gallego, M. (2012). The role of motivation and age in vocabulary knowledge. VIAL, 9, 39-62.

Fontecha, A. F. (2014). Receptive vocabulary knowledge and motivation in CLIL and EFL. Revista de Lingüistica y Lenguas Aplicadas, 9, 23-32. https://doi.org/10.4995/rlyla.2014.2077

Gardner, R. C., \& Lambert, W. E. (1959). Motivational variables in second-language acquisition. Canadian Journal of Psychology/Revue canadienne de psychologie, 13(4), 266-272. https://doi.org/10.1037/h0083787

Gardner, R. C., \& Lambert, W. E. (1972). Attitudes and motivation in second language learning. Rowley, Mass Newbury House Publishers.

Gardner, R. C., \& MacIntyre., P. D. (1991). An instrumental motivation in language study: who says it isn't $\begin{array}{lllll}\text { effective? Studies in Second Language Acquisition, } & \text { 13(1), }\end{array}$ https://doi.org/10.1017/S0272263100009724

Gu, Y. (2003). Vocabulary learning in second language: person, task, context and strategies. TESL-EJ, 7(2), $1-26$.

Higgins, E. T. (1987). Self-Discrepancy: A Theory Relating Self and Affect. Psychological Review, 94(3), 319-340. https://doi.org/10.1037/0033-295X.94.3.319

Islam, M., Lamb, M., \& Chambers, G. (2013). The L2 Motivational Self System and National Interest: A Pakistani perspective. System, 41(2), 231-244. https://doi.org/10.1016/j.system.2013.01.025

Kormos, J., Kiddle, T., \& Csizér, K. (2011). Systems of Goals, Attitudes, and Self-Related Beliefs in Second-Language-Learning Motivation. Applied Linguistics, 32(5), 495-516. https://doi.org/10.1093/applin/amr019

Lamb, M. (2012). A Self System Perspective on Young Adolescents' Motivation to Learn English in Urban and Rural Settings. Language Learning, 62(4), 997-1023. https://doi.org/10.1111/j.1467-9922.2012.00719.x

Laufer, B., \& Nation, P. (1999). A Vocabulary-Size Test of Controlled Productive Ability. Language Testing, 16(1), 33-51. https://doi.org/10.1177/026553229901600103

Markus, H., \& Nurius, P. (1986). Possible Selves. American Psychologist, 41(9), 954-969. https://doi.org/10.1037/0003-066X.41.9.954

Masrai, A., \& Milton, J. (2017). Recognition Vocabulary Knowledge and Intelligence as Predictors of Academic Achievement in EFL Context. TESOL International Journal, 12(1), 128-142.

Meara, P. (1996). The dimensions of lexical competence. In K. M. I. G. Brown (Ed.), Performance and Competence in Second Language Acquisition (pp. 35-53). Cambridge University Press: Cambridge.

Meara, P., \& Milton, J. (2003). The Swansea Levels Test. Newbury: Express.

Milton, J., Wade, J., \& Hopkins, N. (2010). Aural word recognition and oral competence in a foreign language. In R. Chacón-Beltrán, C. Abello-Contesse, \& M. Torreblanca-López (Eds.), Further insights into non-native vocabulary teaching and learning (pp. 83-98). Bristol: Multilingual Matters.

Nation, P. (1990). Teaching and Learning Vocabulary. New York: Heinle \& Heinle.

Nation, P. (2011). Systematizing vocabulary learning. In I. M. Colpaert (Ed.), Peer Perspectives on Systemization (pp. 125-134). Antwerp: University of Antwerp.

Pallant, J. (2010). SPSS Survival Manual: A Step by Step Guide to Data Analysis Using SPSS. Milton Keynes: Open University Press. 
Papi, M. (2010). The L2 Motivational Self System, L2 Anxiety, and Motivated Behavior: a Structural Equation Modeling Approach. System, 38(3), 467-479. https://doi.org/10.1016/j.system.2010.06.011

Qian, D. (1999). Assessing the roles of depth and breadth of vocabulary knowledge in reading comprehension. Canadian Modern Language Review, 56, 282-308.

Read, J. (2004). Research in teaching vocabulary. Annual Review of Applied Linguistics, 24, 146-166. https://doi.org/10.1017/S0267190504000078

Read, J. A. S. (2011). Assessing vocabulary. Cambridge: Cambridge University Press.

Roche, T., \& Harrington, M. (2013). Recognition vocabulary knowledge as a predictor of academic performance in an English as a foreign language setting. Language Testing in Asia, 3(1), 1-13. https://doi.org/10.1186/2229-0443-3-12

Saville-Troike, M. (1984). What really matters in second language learning for academic achievement? . TESOL QUARTERLY, 18(2), 199-219. https://doi.org/10.2307/3586690

Schmitt, N. (2010). Researching vocabulary a vocabulary research manual. Basingstoke: Palgrave Macmillan.

Stæhr, L. S. (2008). Vocabulary size and the skills of listening, reading and writing. Language Learning Journal, 36(2), 139-152. https://doi.org/10.1080/09571730802389975

Tabachnick, B. G., \& Fidell, L. S. (2007). Using Multivariate Statistics (5th ed.). Boston: Pearson Education.

Taguchi, T., Magid, M., \& Papi, M. (2009). The L2 Motivational Self System among Japanese, Chinese and Iranian Learners of English: A Comparative Study. In Z. Dörnyei \& E. Ushioda (Eds.), Motivation, language identity and the L2 self (pp. 66-97). Bristol: Multilingual Matters.

Wilkins, D. A. (1972). Linguistics in Language Teaching. London: Edward Arnold.

Williams, M., \& Burden, R. L. (1997). Psychology for language teachers: A social constructivist approach. Cambridge: Cambridge University Press.

Yashima, T. (2002). Willingness to Communicate in a Second Language: The Japanese EFL context. The Modern Language Journal, 86(1), 54-66. https://doi.org/10.1111/1540-4781.00136

You, C. J., \& Dörnyei, Z. (2016). Language Learning Motivation in China: Results of a Large-Scale Stratified Survey. Applied Linguistics, 37(4), 495-519. https://doi.org/10.1093/applin/amu046

You, C. J., Dörnyei, Z., \& Csizér, K. (2016). Motivation, Vision, and Gender: A Survey of Learners of English in China. Language Learning, 66(1), 94-123. https://doi.org/10.1111/lang.12140

Yu, G. (2010). Lexical diversity in writing and speaking task performances. Applied Linguistics, 31(2), 236-259. https://doi.org/10.1093/applin/amp024

Zhou, M. (2016). The roles of social anxiety, autonomy, and learning orientation in second language learning: A structural equation modeling analysis. System, 63, 89-100. https://doi.org/10.1016/j.system.2016.09.001

\section{Copyrights}

Copyright for this article is retained by the author(s), with first publication rights granted to the journal.

This is an open-access article distributed under the terms and conditions of the Creative Commons Attribution license (http://creativecommons.org/licenses/by/4.0/). 